\title{
A “RETÓRICA CORTÊS” E SUAS SUTILEZAS
}

\section{Courtly rhetoric and its subtleties}

\author{
Profa. Dra. Lênia Márcia Mongelli \\ Professora Titular (sênior) \\ Departamento de Letras Clássicas e Vernáculas (DLCV) \\ Universidade de São Paulo (USP) \\ ORCID: https://orcid.org/0000-0002-0239-2058 \\ E-mail:Lmongelli@gmail.com
}

Recebido em: 04/07/2020

Aprovado em: 09/09/2020

\begin{abstract}
Resumo: Os dois termos que compõem a expressão "retórica cortês", em geral referindo a produção lírica dos trovadores e a prosa de ficção do romance medieval, têm implicações muito específicas: o primeiro remonta à antiguidade greco-romana e foi retomado, com acréscimos e novidades, pelas Artes Poéticas dos séculos XII e XIII; o segundo, cunhado por Gaston Paris em 1883, traz imbricado em si o derivado "cortesia", com suas normas comportamentais que guiaram a sociedade aristocrática e cavaleiresca nas cortes senhoriais do medievo. Para exemplificar as sutilezas de concepção e de estilo que podem resultar da aplicação deste modelo retórico às cantigas galego-portuguesas, tomamos o texto "Senhor genta" (atribuído a João Lobeira, ativo na segunda metade do século XIII), e a segunda versão dele, "Leonoreta, fin roseta", inserta no Amadis de Gaula (1508).
\end{abstract}

Palavras-chave: amor cortês; retórica medieval; poesia trovadoresca.

Abstract: The two terms that compose the expression "courtly rhetoric", generally referring to lyric troubadour production and medieval romance fictional prose, have very specific implications: one of them, "rhetoric", goes back to the Greco-Roman antiquity, and was retrieved, with additions and novelties, by the $12^{\text {th }}$ and $13^{\text {th }}$ centuries Poetic Arts; the other one, "courtly", coined by Gaston Paris in 1883, has embedded in itself the derivative "courtesy", representing the behavioral code which guided the aristocratic and chivalric society in medieval seigneurial courts. In order to exemplify the subtleties of conception and style which may result from the application of this rhetorical model to the Galician-Portuguese songs, we here examine the text "Senhor genta" (attributed to João Lobeira, active in the second half of the $13^{\text {th }}$ century), and its second version, "Leonoreta, fin roseta", inserted in Amadis de Gaula (1508).

Key-words: courtly love; medieval rhetoric; troubadour lyric. 
Por "retórica cortês" entendemos, inicialmente, o sistema normativo que regeu a produção lírica de trovadores e trouvères medievais, bem como as intrigas cultivadas pelos romances de tema amoroso e cavaleiresco, mais ou menos a partir do século XI e estendendo-se firmemente - uma boa parte desses modelos - até, no mínimo, o final do século XVI. Estamos, portanto, em âmbito literário, o que pareceria de apreensão mais delimitada e objetiva, não fossem as formidáveis implicações circunscritas tanto à "retórica" quanto à "cortesia", termo derivado de "cortês" ou "cortesão". Cada um com sua história própria e igualmente longeva: o primeiro remonta à Antiguidade Grecoromana e permanece plenamente atuante nos dias de hoje, sempre aliado a qualificativos específicos ("retórica linguística", "retórica política", "retórica televisiva", "retórica trabalhista", etc.); a ideologia do segundo, no formato que melhor a caracteriza, é mais recente, mas tomou corpo na Idade Média Central - embora com raízes em tradições antigas (as famosas "origens") e com heranças palpáveis pelos séculos afora. Juntos, substantivo e adjetivo sugerem ricas facetas culturais, ultrapassando fronteiras históricas e geográficas, para fixar-se no imaginário coletivo.

A parceria entre "retórica" e "cortesia/cortês" é mais do que justificável, se tivermos como ponto de partida que a retórica tem, por princípio basilar, a arte da persuasão, conseguida pelo exercício severo e continuado do discernimento, em busca das melhores "provas" (ou "entimemas") para convencer o interlocutor (Aristóteles 1999: 16-25); e que o "amor cortês", por seu lado, resume-se à súplica do amante apaixonado, que se serve de vários artifícios para fazer-se aceito pela dama que o rejeita (Duby 1990). Entre os dois, ele e ela, na porfia da conquista, está o discurso amoroso "discurso" este que se estriba nas lições de Platão, Aristóteles, Cícero, Quintiliano e quantos mais se fizeram ouvir entre os eloquentes gregos e romanos (Mosca 1997; Moheno 2016; Hubert 2019), até chegarmos à especificidade e aos requintes das Poéticas medievais (Faral 1962). É a essa estrutura básica - com regras e conveniências de ambas as partes - que se vão somando as novidades, "retóricas" e "corteses", no passar dos séculos.

Das cinco partes em que Cícero e depois Quintiliano dividiram o sistema retórico dito "clássico" - inventio, dispositio, elocutio, actio, memória -, embora as três primeiras tenham presença evidente no conjunto do Trovadorismo, nem por isso as duas últimas são menos significativas, como fartamente mostrou Paul Zumthor (1972; 1993). A inventio costuma ser traduzida pela tópica aristotélica (Curtius 1957: 82 e ss.): conjunto de temas, motivos, "provas" e "argumentos" que, uma vez conhecidos do público/auditório/leitor, tornam mais fácil a comunicação e, portanto, a adesão do interlocutor à causa em questão. No caso do esforço de conquista da amada pelo trovador - de que aqui tratamos -, o largo rol de expedientes temáticos e formais disponíveis configura uma "sintomatologia amorosa", na feliz expressão de Segismundo Spina (1966: 57), a qual vai das sensações físicas às reações psíquicas, das dores concretas às enfermidades da alma. Nas raras vezes em que a amada cede, fá-lo antes de tudo porque tocada por tamanha devoção. Quanto à dispositio, sendo ela a maneira lógica de dispor as partes do discurso (na origem clássica: exórdio / proposição / partição / narração-descrição / argumentação / peroração - Mosca 1997: 28), a própria conformação de uma cantiga (na lírica galego-portuguesa: cantiga de amor, cantiga de amigo e cantiga de escárnio e maldizer, mais sub-espécies - Lopes 2016), com sua organização em versos, rimas, estrofes e refrães, com extensão nunca demasiada (nem mesmo na cansó provençal), levando a imaginação a "enquadrar-se" no molde, facilita e, ao contrário do que se costuma supor, até incentiva a precisão da linguagem para 
conseguir o melhor e mais incisivo efeito, conforme veremos. Com relação à elocutio, ou, mais denotativamente, ao "estilo", referente às escolhas que se fazem, às soluções que se adotam para obter a melhor "expressão", ou seja, a conveniente adequação forma / conteúdo, basta conferir três das mais importantes obras divulgadas por Edmond Faral - Mathieu de Vendôme, Ars versificatoria (1175); Geoffroi de Vinsauf, Poetria Nova (entre 1208-1213); Jean de Garlande, Poetria ou Parisiana (1220) - para se constatar que, firmemente apoiados na retórica antiga (principalmente no Livro III da Retórica aristotélica), os teóricos dos séculos XII e XIII detiveram-se no que eles chamaram "ornamentos do estilo" ou "cores da retórica". Tomaram os tropos - nos termos de hoje, "figuras de linguagem" (de palavras, de construção, de pensamento) - e, com invejável minúcia, puseram-nos a serviço da "amplificação" e da "abreviação", da "descrição" e da "narração", da "afirmação" e da "negação", muitas vezes em impressionantes jogos verbais que criam comparações inusitadas, ousadas antíteses e metáforas a vários níveis (= "ornamento fácil", "ornamento difícil"). Sem contar a rima - importante recurso mnemônico -, com a qual, segundo E. Finazzi-Agrò, a lírica trovadoresca "expulsa a rudimentar pobreza e simplicidade da rima da anterior poesia médio-latina, substituindo-a por uma atenção extrema aos valores fônicos, ao aspecto musical, à estruturação métrica e verbal do discurso." (Lanciani e Tavani, 1993). A aliança com a melodia instrumental foi mais um viés para ajudar a descobrir as riquezas da língua vulgar, então nascendo para vir usurpar o trono do latim.

Em um de seus capítulos mais instigantes de A Letra e a Voz, "Memória e Comunidade" (1987:139), Paul Zumthor chama a atenção, indiretamente, para os laços indissolúveis entre a actio - a "ação" que presentifica o discurso, a sua gestualidade, e a memória - indispensável retenção de conteúdos culturais principalmente em sociedades de tradição oralizante, como são as do Ocidente europeu a partir de finais do Império Romano. Se, no contexto clerical e cortesão dos séculos XII e XIII, os textos teatrais e as chamadas artes praedicandi tinham no palco e no púlpito sua força comunicativa, enfatizando a necessária interação com o "público" (terceiro segmento do tripé retórico) que, em última instância, é quem deve ser "persuadido", da mesma forma o grand chant courtois dos trovadores se fez ouvir pelos quatro cantos dos salões aristocráticos, na voz de seus mais conhecidos intérpretes, os jograis (Page 1989: 8-60)². Espécie de músicos itinerantes, que ganhavam a vida atuando perante um auditório, popular ou cortesão (muitos deles eram patrocinados por membros da nobreza), que cumpria agradar, sua performance incluía desde a execução das cantigas (composições alheias, dos trovadores, e às vezes próprias) até a declamação de textos narrativos, jogos, acrobacias, mímicas etc., na esteira dos histriones antigos (Menéndez Pidal 1991). Só com a perda de fôlego da cultura trovadoresca e com a ascensão da prosa de fíç̧ão é que essas personagens veem reduzidas ou modificadas as suas funções performáticas.

Em suma, nas referências à "retórica cortês", o primeiro termo integra, verticalmente, a natureza constitutiva da essência literária do Trovadorismo. E quanto ao segundo termo? Do ângulo de que aqui o tratamos, a proximidade mais estreita e imediata dele é com o chamado "amor cortês/cortesão", que, por sua vez, se expressa no fin'amors (= fino amor) dos trovadores provençais e, com suas variações específicas, dos trovadores galego-portugueses, significando o "amor perfeito" que deve unir um homem e uma mulher, com vistas a alcançar a joy - a alegria da posse final. A grande questão, quando se trata do assunto, sempre é: até que ponto tudo isto é fantasia, criação dos poetas, e até que ponto corresponde à realidade histórica circundante? 
Nos dias de hoje, essa indagação central perdeu muito de sua razão de ser, por força dos avanços nos estudos literários, linguísticos, filológicos, historiográficos, antropológicos e etnográficos, mostrando a fragilidade de certas fronteiras culturais ${ }^{3}$. Nenhum texto literário pode ser dissociado da sociedade que o engendrou e a que ele retorna, com maior ou menor visibilidade, em sistema de interação. Sendo assim, por mais hiperbólica que possa parecer a "retórica cortês" ao gosto do leitor moderno, ela reflete com precisão as matrizes da sociedade feudal dos séculos XII e XIII, cuja aristocracia - cavaleiresca e clerical - vivia nas cortes dos grandes senhores, às expensas deles, o que obrigava a verdadeiros rituais de comportamento para fazer-se bem aceito (Köhler 1974; Duby 1989; 1990). Daí é que aflora e se firma a "cortesia", cuja longa descendência está atestada, por exemplo, em $O$ Cortesão, de Baldassare Castiglione (publicado pela primeira vez em 1528), espelho comportamental das cortes renascentistas, e até no vocábulo "cavalheiro", cujo étimo, caval., é o mesmo de "cavaleiro" e está dicionarizado como "que ou aquele que possui educação esmerada; delicado; gentil; que ou aquele que possui bons sentimentos". Ou seja, os ademanes de salão pressupunham inclusive as virtudes morais.

Já se sabe, então, que a ficção medieval, do tipo aqui focalizado, é antes de tudo um "jogo" - a que a retórica e seus recursos se adequam como luva. O caminho de conquista da dama, sendo ela casada, não é fácil, é ambíguo: de um lado, o amante fazse humilde, "vassalo" - como manda o figurino do feudalismo -, aproximando-se aos poucos (há "graus" nesta ascensão...), recuando ao menor sinal de rejeição e prosseguindo arduamente, conforme as exigências dela e buscando jamais magoá-la com excessos que arranhem a "mesura" - o indispensável auto-controle, em sociedade de orientações cristãs; de outro lado, o que o amante aspira é, ao fim e ao cabo, à posse física dela, o que põe à prova a sua virilidade de cavaleiro audaz e os seus anseios sexuais, trazendo-lhe enormes riscos, pois o marido dela é, não poucas vezes, o senhor que o sustenta. Depreende-se, desta polaridade, um dos mais paradoxais e desnorteantes aspectos da cartilha amatória cortês: se essa Dama é inacessível, divinizada pelos processos descritivos e por paradigmas de santidade (como a Virgem Maria), feita efígie por quem o amante se apaixona antes mesmo de conhecê-la e perante quem treme a um simples olhar, ela é também a Mulher por quem ele nutre feroz desejo, sendo a possibilidade de vê-la no próprio leito um sonho de conquista masculino, de homem solteiro e bem nascido, que, podendo ter qualquer donzela, vilã ou não, almeja troféu mais alto, inclusive para granjear sua benemerência e seu apoio no acesso às regalias do meio aristocrático. Espiritualidade e erotismo andam aqui a braços dados (Verdon 1996)! Um jogo, como se disse, estudado detalhadamente por Duby (1990).

Mas não tão fantasioso que não esteja fortemente ancorado na História (Huizinga 1978) e nem tão evasivo que dele não tivessem se beneficiado a política da Igreja e a da Realeza. É no contexto do feudalismo que se constrói a relação de "serviço" (geralmente militar) prestado pelo "servo" em condição de "vassalagem" ao "senhor", que, em troca, assume a responsabilidade de sustentá-lo - portanto, elo com obrigações recíprocas (mas não de igualdade) entre dois homens. Se o senhor se compromete a proteger o seu vassus, este, por sua vez, lhe retribui com absoluta fidelidade e devoção, defendendo com fé os seus interesses ${ }^{4}$. A evolução desse quadro conta com o dinamismo e a criatividade do século XII para estender seus tentáculos: período de grande explosão demográfica; de crescimento da produção agrícola e artesanal; de surgimento de novas e numerosas cidades; de multiplicação dos castelos e principados opulentos; de identificação de uma nobreza cavaleiresca - com culminância 
nas Ordens Militares e na marcante participação delas nas Cruzadas; da chamada "Revolução Papal", a colocar em acirrado confronto de poderes o Papa e o Imperador (por conta, dentre outras razões, da assim chamada "Reforma Gregoriana" e seus rígidos esforços para moralizar a Igreja ${ }^{5}$ ); de nascimento das universidades; de paulatina consolidação das línguas vernáculas; de revalorização de vários aspectos da cultura greco-latina etc. - ambiência das mais favoráveis ao incremento e às turbulências da vida social, cujas festas, justas e torneios deixaram seus rastros pelos séculos afora, emblemáticos nos livros de cavalarias quinhentistas.

Os desregramentos implícitos nessa vida áulica eivada de contradições, de perplexidades e de pujança cultural não interessavam a nenhum dos lados, clero ou realeza. Nesse sentido, se a "cortesia" colaborava para colocar um pouco de freio e de limite nas disputas, nas ambições desmesuradas, nos atrevimentos das conquistas e na luxúria comprometedora da paz espiritual - então ela, a "cortesia", era inquestionavelmente salutar à sociedade nascente na altura em que vicejava a lírica trovadoresca e o romance aventuroso. A "retórica cortês" é a arte de bem falar que comparece como um dos quesitos fundamentais para a arte de bem viver, conforme quiseram e demonstraram também os trovadores medievais. É a "voz" deles que merece ser ouvida!

II - Tomemos como exemplo João Lobeira (ativo na segunda metade do séc. XIII) e a extraordinária cantiga "Senhor genta" (ou Leonoreta), a ele atribuída ${ }^{6}$. Aqui será possível acompanhar, em sua maestria, as "sutilezas" referidas no título deste artigo:

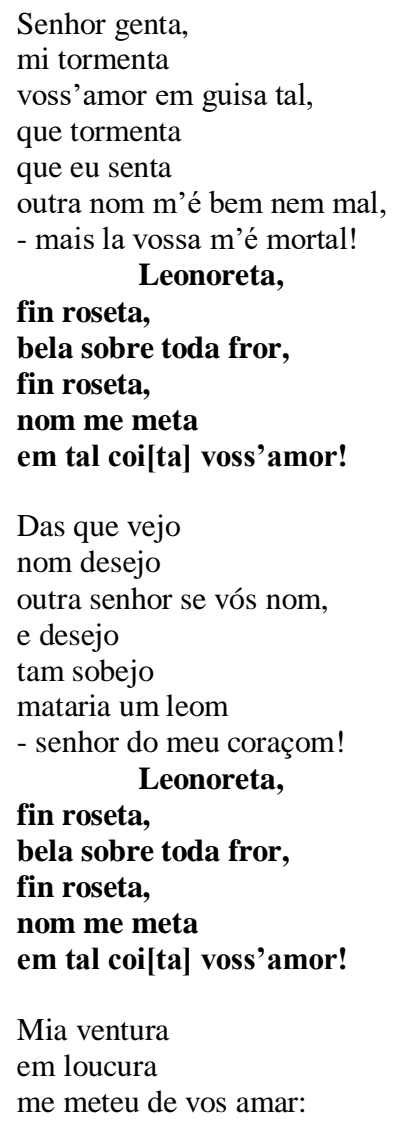




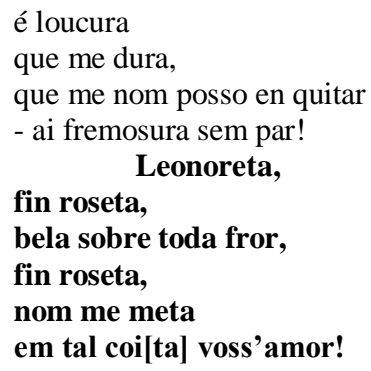

Como se poderá verificar na Bibliografia condizente (nota 8), os dados biográficos referentes a João Lobeira são cheios de lacunas, e nem o texto acima é com certeza de sua autoria (dito "espúrio"), porque destoa bastante do resto de sua escassa produção. Do ponto de vista formal, é uma cantiga "de refrão", com três estrofes singulares (setilhas) e o refrão (sextilha), com rimas graves e agudas,

\section{a3' a3'b7 a3' a3' b7 b7 / C3' C3' D7 C3' C3' D7}

ou, na instigante sugestão de leitura de Giuseppe Tavani, construindo rimas internas, pode-se obter o seguinte esquema, de total regularidade métrica 7:

\section{a7'b7a7'b7b7 / C7'D7C7'D7}

A primeira opção tem sido a adotada pela crítica, que a considera em harmonia com os usos eruditos relativos a lais e descordos provençais e franceses (Lanciani e Tavani 1993). De fato, a heterometria do arranjo em descordo parece bastante eficaz para sugerir os tormentos de sentir-se amante rejeitado, pois coloca em situação de rima, no destaque, parelhas concisas como "desejo / tam sobejo" ou "mia ventura / em loucura", ecoando fortemente extremos sentimentais, aparentemente inconciliáveis.

O texto desenvolve-se dentro da mais genuína argumentação retórica, a começar do vocativo de abertura e sua função exordial - "Senhor genta" (= gentil) -, ocultando de início o nome da dama visada, que só aparece no refrão. Note-se que ela, introduzida delicadamente no vocativo, surge muito distante da paixão que provoca e da "coita" (= sofrimento) como sua consequência direta. Os excessos da mágoa externada - o tormento mortal; o desejo comparado à força de um leão; a loucura desestabilizadora e durável; a impotência - não se curam pela contemplação da "fremosura sem par"; pelo contrário, à revelia do implorante namorado, o coração está dominado pela "bela sobre toda fror", para a qual as outras não são páreo - tópico de comparação que enaltece a amada como "a única". Reações assim exacerbadas - desenvolvidas segundo a técnica da amplificatio -, que principiam pela descriptio puellae (apelo visual aos encantos femininos, de longa tradição, inclusive bíblica - Curtius 1957:106), são a marca registrada das cantigas de amor galego-portuguesas.

Além do preciosismo e da singularidade do vocabulário que percorre o texto, justificando sua datação tardia (fim do século XIII ou posterior, em zona temporal fronteiriça) e distanciando-o, no conjunto, do universo linguístico usual à lírica galegoportuguesa, o refrão merece atenção, quando menos pela superior qualidade de sua construção, ritmicamente tão musical. Note-se que os três primeiros versos dizem respeito a ela, a amada, e os três últimos, equilibradamente, a ele, o amante, temeroso ("não me meta") e surpreso ("tal coi[ta]") quanto ao que lhe acontece e pode vir a acontecer. Entre o vocativo "Leonoreta" e a oração verbal "nom me meta", o fôlego fica como que suspenso pela sequência de delicados panegíricos - "fin roseta" (repetido) e 
"bela sobre toda fror". "Fin roseta", com valor adjetival e metonímico para "Leonoreta", é expressão duplamente rara: quanto a "fin", Carolina Michaëlis dedicou-lhe um dos seus concisos e precisos artigos, em que, dentre outros aspectos e tomando por base as línguas românicas, lembra o fato "de o mais clássico dos Latinos [Cícero] se haver servido de expressões populares em que finis equivalia a extremo, último, supremo, sumo". E citando uma série de exemplos franceses (arcaicos, clássicos e populares), mostra como nessa língua "o nome fin serviu e serve de advérbio [...]", tendo finalmente passado a "adjectivo superlativo. Un fin amant é o nec plus ultra dos amantes" (Vasconcelos 1969: 184-185). Quanto a "roseta", é termo único na lírica galegoportuguesa medieval, não familiarizada com os diminutivos, mais comuns nas pastorelas e próprios dos gêneros popularizantes (aab). Mesmo "rosa", a essa altura, não é corriqueiro; temos duas ocorrências na lírica profana: uma da autoria de Vidal, português de origem judaica e natural de Elvas, na cantiga de amor Faz-m' agora por si morrer; e outra, em uma cantiga, também tardia e "espúria", atribuída a Alfonso XI, En un tiempo cogi flores.

Por fim, quem é a personagem Leonoreta? O fato de ela aparecer nomeada em uma cantiga de amor configura "quebra de protocolo", pois o princípio cortesão da mesura (= moderação, justa medida) impedia pronunciar o nome da "senhor", substituído por uma espécie de "pseudônimo", o senhal da lírica da Provença. No caso em foco, essa Leonoreta - que a métrica exige se leia "Lenoreta" - mantém o segredo, não o desvenda: será ela, supõe Vicente Beltrán, a nobre sevilhana D. Leonor de Guzmán (1310-1351), "a Favorita”, que, tendo sido casada com Juan de Velasco, morto sem lhe dar descendentes (ela com dezessete anos), foi amante de Alfonso XI de Castela (1311-1350), com quem teve 10 filhos?8 Pelo menos, a suposição bem justifica o admirável refinamento da linguagem, adequada à destinatária - no mais legítimo emprego da "retórica cortês".

Tanto assim que a história desse texto não para por aí. Há uma segunda versão dele, bem diferente - versão que, na verdade, trouxe notoriedade à primeira. E nem foi por suas reconhecidas qualidades literárias que ele se sobressaiu; trata-se, antes, de uma questão de disputa de nacionalidade para a redação primitiva da famosa novela de cavalaria Amadis de Gaula $(1508)^{\mathbf{9}}$ - se originalmente espanhola, se portuguesa -, obra na qual se insere a outra versão, em espanhol, de Leonoreta:

Leonoreta, fin roseta

blanca sobre toda flor,

fin roseta, no me meta

en tal cuita vuestro amor.

Sin ventura yo en locura

me metí

en vos amar, es locura

que me dura,

sin que poder (sic) apartar;

o hermosura sin par,

que me da pena y dulçor!,

fin roseta, no me meta

en tal cuita vuestro amor. 


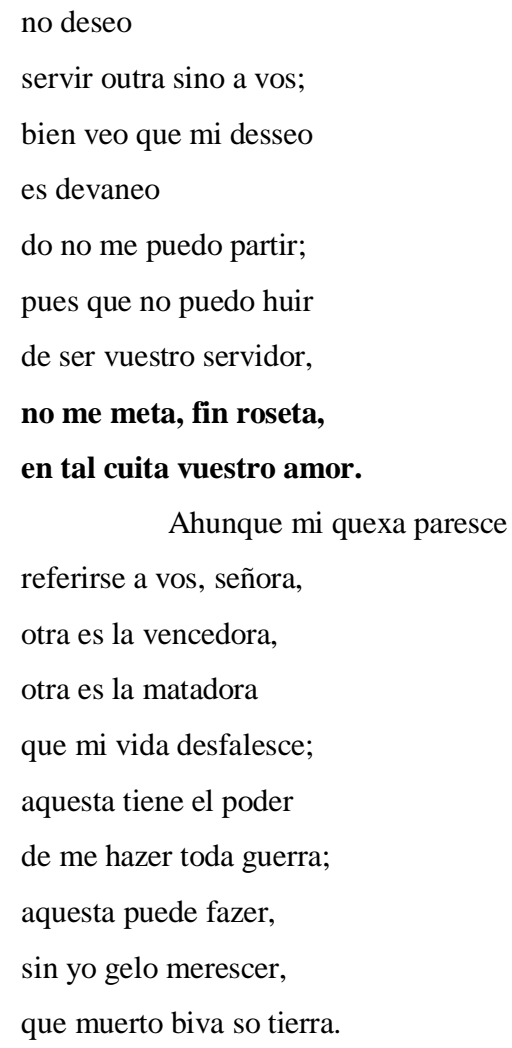

Outro texto, outro contexto, outro público - portanto, outra forma de expressão, embora "acrescentada" à matriz, perfeitamente reconhecível. Lobeira (ou um Anônimo?), como vimos, apresenta três estrofes (sétimas ou heptetos), além do refrão (sextetos); o Amadis igualmente, porém com quatro diferenças: a) aqui, a primeira estrofe é uma nona e as outras duas são décimas; (o refrão, uma quadra) b) inverte-se a ordem: a terceira estrofe do poema 1 torna-se a primeira do poema 2 , e a segunda do poema 1 é a primeira do poema 2 ; c) em Lobeira, não temos a ultima estrofe do Amadis; neste, não há a primeira estrofe de Lobeira; d) no Amadis, os dois últimos versos da primeira e da segunda estrofes repetem (nesta, com variação) os dois últimos versos do refrão, o que define o villancico espanhol ou o vilancete galego-português (Lanciani e Tavani 1993), em moda a partir do século XV. Mantém-se a heterometria (com possibilidades de rimas internas) na segunda e terceira estrofes10. Quanto ao refrão, está igual nos dois poemas, salvo pela notória e incisiva substituição de "bela" por "blanca".

Como se justifica a inserção de Leonoreta no Amadis de Gaula - mistura de poesia e prosa em uma mesma obra (recurso conhecido por prosimetrum), que remonta à Antiguidade e que permanece pelos séculos afora, muito bem aclimatado aos livros de cavalarias? $\mathrm{O}$ episódio é bastante secundário na narrativa, frente a outros cruciais: tratase de uma nova aventura ameaçadora na corte do rei Lisuarte, pai de Oriana, a Sem-Par (protagonista), dona e senhora do coração de Amadis. Quatro gigantes poderosos apresentam-se e ameaçam invadir o reino, a menos que Lisuarte conceda a um deles a mão de sua filha - a pôr em risco a sorte futura dos amantes, Amadis e Oriana. Em puro estilo de heroísmo cavaleiresco, a resposta do rei é contundente: 
Cavallero, mejor es la guerra peligrosa que la paz deshonrada, que mala cuenta podría yo dar aquel Señor que en tal alteza me puso, si por falta de coraçón con tanta mengua y tanto abiltamiento la abaxasse; y agora os podéis ir, y dezildes que antes querría la guerra todos los días de mi vida con ellos y al cabo en ella morir, que otorgar la paz que me demandan. (Montalvo 1987: 764).

Depois que os inimigos vão embora, e naquele intermezzo "cortês" para aliviar a tensão, o soberano manda chamar a filha caçula, Leonoreta, acompanhada de todas as suas doze "donzellitas", e pede-lhe que cante e dance a canción que por amor dela havia feito Amadis.

Porém, o galanteio do cavaleiro à pequena tem supostamente uma outra história: estando na corte "a folgar" a rainha Brisena, mais sua filha Oriana e outras damas, brincaram com Leonoreta para que solicitasse de Amadis "que fuesse su cavallero y la sirviesse muy bien". A garota toma a sério o pedido e recebe do cavaleiro a promessa solene de que será seu servidor; para selar o ato, divertidamente compartilhado pelos presentes, há troca de "prendas": ela oferta-lhe "un prendedero de oro con unas piedras muy ricas" e ele retribui com o texto do poema, que, evidentemente, não visava a Leonoreta, mas a sua irmã, Oriana, por quem o herói já se consumia de amores. Isto talvez explique um dos saborosos e específicos aspectos desta cantiga, também imersa em ambigüidades: se a extraordinária delicadeza do refrão agora atende à mimosa destinatária "fin roseta" - etérea e cheia de graciosidade em sua "brancura" e "beleza" infantis -, as estrofes, no entanto, ainda se desenvolvem sob o signo da "loucura" e do "devaneio" vãos, porque "otra es la vencedora / otra es la matadora", a fazer do amante um paradoxal "morto-vivo" sobre a terra - conforme a terceira estrofe recusada pelos críticos, aparentemente acrescentada, então, para resolver a dupla identidade da receptora, Oriana ou sua irmãzinha. O trovador tem absoluta consciência dos esmeros retóricos de que se serve!

Tanto que exclui a primeira estrofe do texto 1, cujo vocativo, "Senhor genta", estabelece um diálogo direto com a dama ausente e invoca o "tormento mortal" de amála - sentimento hiperbólico em nada adequado a uma criança, ainda mais coroado pelo "sobejo desejo" que se manifesta com a força de "um leom". O segundo texto ameniza a potência avassaladora do primeiro: em lugar de "mia ventura" - ou "sorte", desencadeadora de uma "loucura" involuntária e, talvez por isso mesmo, incontrolável o segundo texto opta por um "yo" que toma a decisão sobre seu próprio estado, conforme diz o verbo "me meti", contra a terceira pessoa "me meteu" do texto precedente. Do mesmo modo, a antítese "pena e dulçor" faz do "tormento" do poema anterior um sentimento agridoce, passível de suportar. E na segunda estrofe, aquele "desseo" nascido do "devaneo", mesmo que o poeta confesse "do no me puedo partir", coloca a realidade em outro patamar, o da pura abstração sim, mas avaliada por um "eu" que mede a extensão de seus danos. Nesse universo mental diáfano, não cabe a presença maciça do "leom" - ausência das mais significativas, como veremos -, e a "flor branca", altamente simbólica para o medievo (Patoureau 2004: 135-172), ascende um degrau acima de "toda fror". 
III - Aqui chegados, é possível observar, com clareza, que a "Senhor genta" e a "blanca Leonoreta" determinaram o "tom" discursivo de ambas as cantigas, porque são elas as "damas" a serem "persuadidas" - a sério ou de brincadeira -, exigindo da "voz" poética a consciência linguística e social dessas duas presenças. Daí o apelo subliminarmente muito mais enfático do primeiro texto; por isso a força do desejo que "mataria um leom" não cabe no segundo.

Por que "leão", em imagem bastante singular? A ocorrência é raríssima na lírica galego-portuguesa, comparece apenas em duas cantigas: além da que estamos examinando, está também em uma conhecida tenção entre Pero da Ponte e Afonso Anes de Cotom - Pero da Pont', e [m] um vosso cantar (Pereiro 1996: 206-207; Lopes 2016). Já na lírica provençal, segundo um interessante levantamento feito por Mercedes Brea, a presença do leão - "cruel, forte e ousado, símbolo de orgulho e de dureza" - é mais frequente: R. de Vaqueiras, D. de Pradas, A. de Maruelh, G. Magret e inclusive Marcabrú, que, satirizando prostitutas, compara-as a esse animal (Brea 1994: 419). Mas quanto aos provençais, o campeão das aproximações entre os sentimentos humanos e os dos animais é Rigaut de Berbezilh, sendo sua canção Atressi com l'orifanz uma das mais conhecidas, com ampla repercussão na Itália e na Catalunha durante a Idade Média (Riquer 2001: 290-292): não só o elefante, o urso e o cervo são chamados à baila para representar as dores do amante desprezado, como também a fabulosa fênix - o belo pássaro mitológico grego que, quando morre por combustão, renasce das próprias cinzas.

Antes de voltar ao leão, pontuemos o que parece fundamental, para não incorrer em anacronia: o mundo zoológico antigo, greco-romano e medieval, é muito diferente das nossas concepções modernas - aquelas que se podem mais ou menos datar a partir dos estudos e da taxonomia realizados pelo botânico e zoólogo sueco Carlos Lineu (1707-1778), o primeiro a tentar uma nomenclatura binomial (por exemplo, leão = panthera leo) e a classificação científica dos animais, das plantas e dos minerais. Se o século XIX assiste à evolução das ciências físicas e, no tema em pauta, ao darwinismo, com sua profunda e duradoura repercussão, não menos complexas são as contribuições de hoje trazidas pelos geógrafos, pelos ambientalistas, pelos etnólogos, pelos sociólogos e, principalmente, pela Genética - indispensável auxiliar dos biólogos para entender a morfologia de cada espécie e sua relação com o tipo de habitat ideal à preservação dela. Em se tratando dos felinos - que os americanos dizem "wild cats" (1995) -, eles estão distribuídos por "linhagens", segundo a região zoogeográfica em que vivem, sendo chamada de Panthera a linhagem específica em que se acomoda o leão. ${ }^{11}$

Quanto à zoologia antiga, que a Idade Média recolheu em "bestiários" - ou Livre des natures des animaux -, dois reparos prévios fazem-se necessários: 1) a origem desta tradição é grega, e no original primitivo perdido, os especialistas supõem que o autor desconhecido, mais naturalista, partisse da observação direta da Natureza (Lazaris 2005, 141-167). Esse texto seminal, Physiologus (48 capítulos), provavelmente transmitido pelos sírios ao mundo árabe, foi escrito em grego (Alexandria?), datado por alguns do século II de nossa era. Muito popular durante a época bizantina, conhecem-se dele quatro versões em latim, traduzidas talvez no século IV (elencando 56 animais), compondo o que ficou conhecido como "bestiário latino", cujo modelo, de perfil cristão, passará aos séculos seguintes, com objetivos claramente didáticos e educativos, visando a formar cidadãos virtuosos (Varandas 2006). 
2) A partir dos séculos XI e XII, os bestiários multiplicam-se na França e na Inglaterra, alargando de tal forma os seus interesses, que muitos adquirem a feição "enciclopédica" desenvolvida ao tempo, século XIII, na linha da erudição herdada da Antiguidade, e permitindo toda sorte de adaptações, como o "bestiário filosófico" ou o "bestiário de amor". Exemplo dos mais significativos é o Le Bestiaire d'Amour, de Richard de Fournival (1201-c.1260), em que o autor utiliza seus conhecimentos de História Natural a serviço do Amor e da tentativa de conquistar sua Dama. De posse do código da galanteria, que conhece e desenvolve muito bem, acrescenta a ideia criativa de oferecer à amada a chance de resposta, dada por ela nos mesmos parâmetros linguísticos do cortejador (Fournival 1860).

Porém, nesse longo trânsito entre a zoologia antiga e a medieval, vozes importantes foram se fazendo ouvir, adaptando à sua maneira inclusive fábulas orientais (Papavero 2017), de modo que o nosso leão vai ganhando as cores que fizeram dele, posteriormente, o "rei dos animais". Três fontes são citadas como pontos de referência para a presença dos animais na literatura culta, bíblica, popular e folclórica reunida nos bestiários medievais: Historia Animalium, de Aristóteles (384-322 aC); Historia Naturalis, de Plínio o Velho (23-79 dC); Etymologiae, de Isidoro de Sevilha (560-636) sendo que este último autor é, para alguns pesquisadores (Bergot 2015), o que recolheu as informações precedentes e serviu de mediador para levá-las aos pósteros ${ }^{12}$. Se o primeiro autor forneceu as bases para uma verdadeira "psicologia" das "bestas" (2014 $12-13 ; 291$ ) e se o segundo tem histórias muito atraentes sobre o leão (como, por exemplo, a "gratidão" do bicho para com um caçador que the arrancou um espinho da pata, livrando-o da dor, e o seu "salvador", de ser devorado - Plínio 2003: 142-143), Isidoro começa por estabelecer quem pertence ao grupo das "bestas - leões, pardos (= leopardos), tigres, lobos e raposas, bem como "cachorros, macacos e outros que mostrem sua crueldade com a boca e com as unhas" -, e o porquê de o conjunto de tais "bestas" ser assim designado: "pela violência com que manifestam sua ferocidade" (Isidoro 1993, v.II:69). O nome de "feras", também atribuído ao grupo, deve-se a usarem "sua natural liberdade e se deixarem levar pelo próprio desejo", segundo a vontade de vagar de um lado para o outro, ao sabor do capricho.

De acordo com Isidoro, o leão grego interpreta-se em latim como "rei", uma vez que é "a mais importante de todas as bestas"13. A descrição de suas qualidades superiores é humanizada: os leões maiores e de juba curta são os mais ferozes - a fronte e a cauda revelam seu caráter; o peito, o valor; a cabeça, a decisão. Quando se vêm cercados, olham para o chão, para não atemorizar-se com as armas. Ao dormir, mantêm os olhos abertos, vigiando; se caminham, apagam os próprios rastros com a cauda, para despistar os caçadores. E quando têm filhotes, que dormem durante três dias e três noites seguidas, estes são despertados pelos bramidos e rugidos paternos, fazendo estremecer o lugar que lhes serve de covil (o que depois se dirá que o leão reanima os filhos "mortos" com a força de seu "hálito" - por exemplo, Theobaldi 1972, 27). E, por último, numerosos exemplos comprovam a "clemência" do leão: perdoa aos prostrados; permite o retorno dos cativos; mata homens apenas quando muito faminto.

Este retrato ambíguo do leão - mau per natura, mas também "generoso" -, tem o respaldo de auctoritas como Santo Agostinho, 345-430, (ou Isidoro não remontaria a Aristóteles e a Plínio, mesmo com a ressalva do "segundo dizem" = dicitur) e da própria Bíblia: Agostinho, não apenas no manual exegético que é A Doutrina Cristã insiste na relatividade do julgamento humano diante de "expressões figuradas" que nos impõem repensar e aceitar as "diferenças de costumes" plasmadas no Antigo Testamento (2002, 
Livro III: 169 e ss.), como ainda, na Cidade de Deus. Contra os Pagãos, referindo-se às "criaturas monstruosas", diz benevolente, em passagem célebre: "Deus, Criador de todas as coisas, conhece onde, quando e o que é ou foi oportuno criar e, ademais, conhece a beleza do universo e a semelhança ou diversidade das partes que a compõem" (1990, v. II : 129); nas Sagradas Escrituras, essa força da bênção divina é genesíaca: "E a todos os animais da terra, a todas as aves dos céus, a tudo o que se arrasta sobre a terra, e em que haja sopro de vida, eu dou toda a erva verde por alimento. E assim se fez. Deus contemplou toda a sua obra e viu que tudo era muito bom." (Gn, 1, 30-31). Aliás, a Bíblia está povoada de leões ("mencionados mais de quarenta vezes", Woensel 2001:207), que ora surgem sob aplausos - "o mais bravo dos animais,/que não recua diante de nada" (Prov 30, 30); Judá é o "filhote de leão", aquele "de quem não se apartará o cetro nem o bastão", até que venha aquele "a quem todos os povos obedecerão" (Gn 49, 9), aquele que, no Apocalipse, é o "Leão da tribo de Judá, o descendente de Davi", que acha o "meio de abrir o livro sagrado e os sete selos" $(5,5)$; ora comparecem sob condenação - "Salvai-me a mim, mísero, das fauces do leão" (Sal 21,22); "Sede sóbrios e vigiai. Vosso adversário, o demônio, anda ao redor de vós como o leão que ruge, buscando a quem devorar." $(1 \text { Pe } 5,8)^{14}$.

Sair vencedor de uma luta contra o temível e bravio leão tornou lendários personagens bíblicos como Sansão e o próprio Davi, em narrativas que passaram à História e aos exempla medievais: assim que Sansão decidiu desposar a filha de um filisteu, do povo inimigo de Israel, desceu a Tamna para pedi-la em casamento e, "quando chegaram às vinhas de Tamna, apareceu de repente um leão rugindo, que arremeteu contra ele. O Espírito do Senhor apossou-se de Sansão e ele despedaçou o leão como se fosse um cabrito, sem ter coisa alguma na mão" (Jz, 14) - vitória portentosa, só possível por interferência direta de Deus, favorável aos israelitas. A batalha épica de Davi contra Golias não é menos grandiosa: sendo o mais novo dos quatro irmãos e desacreditado por sua juventude diante do gigantesco adversário, ele apresenta-se a Saul e diz: "Quando o teu servo apascentava as ovelhas do seu pai e vinha um leão ou um urso roubar uma ovelha do rebanho, eu o perseguia e o matava, tirando-lhe a ovelha da boca. E se ele se levantava contra mim, agarrava-o pela goela e estrangulava-o. Assim como o teu servo matou o leão e o urso, assim fará ele a este filisteu incircunciso, que insultou o exército do Deus vivo. O Senhor, acrescentou, que me salvou das garras do leão e do urso, salvar-me-á também das mãos deste filisteu". Impressionado, Saul rende-se: "que o Senhor seja contigo!” (I Sam, 17, 34-37). Como diz Pastoureau, nos dois episódios temos quase um "rito de passagem" $(2004,56)$, do tipo que costuma distinguir os heróis e os santos.

Se desde o Oriente antigo cercar-se de feras ou revestir-se da pele delas era signo de riqueza e de poder (Buquet 2011) - costume que se manteve entre os grandes senhores feudais e, até hoje, em certas tribos indígenas ("Wild Cats" 1995) -, nenhuma honraria é mais dignificante, quintessência para o espírito da cristandade, do que a simbologia crística que eleva o leão acima de todos os outros animais. Em uma das versões do Physiologus (1979, 3-4), a comparação analógica com o Filho do Homem é imediata, referente às "três naturezas do leão": a) assim como o leão apaga suas pegadas para não ser encontrado, também "nosso Salvador, o leão espiritual da tribo de Judá, da raiz de Davi, tendo sido enviado por seu Pai, esconde sua divina natureza dos incrédulos judeus"; b) assim como o leão mantém os olhos abertos mesmo quando adormecido, no Cântico dos Cânticos, "a noiva testemunha, dizendo: 'Eu dormia, mas meu coração velava. / Eis a voz do meu amado. Ele bate'," $(5,2)$; c) assim como a leoa, supondo 
mortos os filhos recém-nascidos, aguarda a vinda do pai para fazê-los reviver, igualmente "procedeu o poderoso Pai de todos os despertos dentre os mortos, no terceiro dia do primogênito de todas as criaturas" (Col 1, 15-18). E na tradução espanhola, invoca-se a Mãe sagrada:

El león significa el Hijo de la virgen María; es, sin duda alguna, el rey de todos los hombres; por su propia naturaleza, tiene poder sobre todas las criaturas. Con fiera actitud y terrible venganza se aparecerá a los judios cuando los juzgue, porque obraron mal cuando lo clavaron en la cruz, y debido a esta acción perversa no tienen rey propio." (Bestiario Medieval, 1986: 24)

IV - De volta às duas magníficas cantigas que nos levaram por tantas e tão diversas veredas, podemos concluir: Lobeira, ou outro, e seu "adaptador" espanhol, com superior manuseio das prescrições tanto da retórica clássica e das poéticas medievais quanto da cortesia palaciana, puseram em prática, no sentido mais elevado do termo, o princípio do "decoro" de Horácio, exposto na Epistula ad Pisones (14-13 aC): "Se não posso nem sei respeitar o domínio e o tom de cada gênero literário, por que saudar em mim um poeta?". Mais adiante, referindo-se ao teatro e sugerindo que "não se mostrem em cena ações que convém se passem dentro e furtem-se muitas aos olhos", justifica com rigor: "Não vá Medéia trucidar os filhos à vista do público; nem o abominável Atreu cozer vísceras humanas, nem se transmudará Procne em ave, ou Cadmo em serpente diante de todos. Descreio e abomino tudo o que for mostrado assim" (1990 57, $60)$.

Em dois pormenores chave - eis a sutileza! - ambas cantigas são, por assim dizer, medularmente horacianas, garantindo o equilíbrio do conjunto:

1 - nos adjetivos "bela" e "blanca": a concretude do primeiro é um apelo quase palpável aos atributos físicos da amada, àqueles que agradam primeiro aos olhos que observam e cobiçam a "Senhor genta", cuja simples imagem provoca o "tormento mortal". Conforme Umberto Eco cita Isidoro de Sevilha, "'beleza física' vem de venis, isto é, do sangue, enquanto formosus, 'belo', vem de formo, que é o calor que move o sangue; de sangue vem também sanus, que se diz de quem não é pálido" (Eco 2007, 113). O teor diáfano do segundo ${ }^{15}$ pode ser lembrado por palavras do mesmo Eco, atento, embora, à necessidade de contextualização das afirmações, como, por exemplo, as que tece com relação à presença da "luz" nas catedrais góticas e aos efeitos dela na disseminação das cores: "A Idade Média acredita que cada coisa no universo tem um significado sobrenatural e que o mundo é como um livro escrito pela mão de Deus. Cada animal tem uma significação moral ou mística, assim como cada pedra e cada erva (e isso é narrado nos bestiários, lapidários e herbários). É costume atribuir valores positivos ou negativos também às cores..." $(2007,121)^{16}$. No caso, a "pena" causada pela candidez "blanca" é positiva, porque cheia de "dulçor".

2 - Nos dois textos, o "desejo" mal resolvido é o topos, o leitmotiv do canto amoroso: enquanto no primeiro ele é "tam sobejo" que "mataria um leom", no segundo ele é "devaneo". Com relação ao desejo que exorbita, que eroticamente (Verdon 1996, 78; 2006, 105) "sobeja" no advérbio de intensidade "tam", o histórico do "leom", como vimos, justifica-o plenamente: quer na Antiguidade quer na Idade Média, matar o 
bicho é proeza hercúlea, exige a força de um Sansão ou a fé cheia de destreza de um Davi ou, ainda, a capacidade de resistência dos mártires, que tantas vezes serviram de pasto aos felinos nas arenas romanas, como Santo Inácio de Antioquia (35- c. 98/107). Já o desejo que é "devaneo", limítrofe do "sonho"17 e de toda a sua complexidade introspectiva, aciona um "eu" então nascendo timidamente, ainda submisso a imperiosas fronteiras "vassálicas": "O sonho (ou melhor, sua memória evanescente, e a narrativa reconstruída a partir da atividade imaginária peculiar ao dormir, sem a qual o sonho não poderia socialmente existir) é um fenômeno universal. Universal é também o estatuto ambíguo dos sonhos, que fascinam e sempre inquietam: porque eles testemunham uma atividade do espírito no momento mesmo em que, paradoxalmente, $o$ homem está imerso em um estado de letargia e de inação às vezes comparado à morte..." (Schmitt 2001, 295 e ss.). Qualquer dos dois "desejos", explicitamente carnal ou sonhadoramente sublimado, esbarra na "cortesia", está interdito, conforme os inflexíveis mandamentos da "retórica". Há que contê-los, a ambos!

Essas duas Leonoretas, tão lindas que destronaram qualquer flor, não ficaram circunscritas à lira melodiosa dos trovadores galego-portugueses; Cecília Meireles (1901-1964) ouviu-a e, em dicção muito própria, retomou-as para criar "a sua" Leonoreta, literariamente majestosa como as antecessoras:

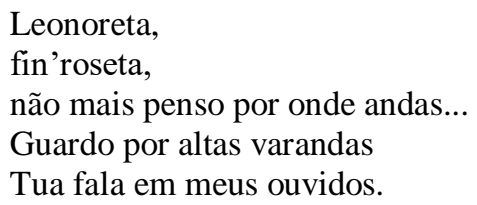

\section{Bibliografia}

\section{Fontes}

ARISTÓTELES. Arte Retórica. Arte Poética. São Paulo: Difusão Europeia do Livro, 1964.

ARISTÓTELES. História dos Animais. São Paulo: Martins Fontes, 2014.

BESTIÁRIO Medieval. Ignacio Malaxecheverría (ed.). Madrid: Siruela, 1986.

BÍBLIA Sagrada. 57ª ed. São Paulo: Editora Ave Maria, 1957.

CAPEllanus, A. / EL CAPELlAN, A. De Amore / Tratado sobre El Amor. Inés Creixell Vidal-Quadras (ed.), Barcelona: El Festin de Esopo, 1985. [Ed. bras.: CAPELÃO, A. Tratado do Amor Cortês. São Paulo: Martins Fontes, 2000.]

CASTIGLIIONE, B. O Cortesão. São Paulo: Martins Fontes, 1997.

CÍCERO, De l'Orateur. Texte établit, traduit e annoté par François Richard. Paris: Garnier, s/d. 
FARAL, E. Les Arts Poétiques du XII ${ }^{\mathrm{e}}$ et du XIII ${ }^{\mathrm{e}}$ Siècle. Paris: Librairie Honoré Champion, 1962.

HORÁCIO. Epistula ad Pisones. In: A Poética Clássica. São Paulo: Cultrix, 1990, pp. 53-68.

ISIDORO DE SEVILLA. Etimologías. Texto preparado por Wallace M. Lindsay, trad. espanhola de José Oroz Reta \& Manuel Marcos Casquero. 2. ed. Madrid: Biblioteca de Autores Cristianos, 1993, 2 vols.

LATINI, B. Li Livres dou Tresor. Francis J. Carmody (ed.). Genève: Slatkine Reprints, 1875.

Lírica Profana Galego-Portuguesa. BREA, M. (coord.). Santiago de Compostela: 1996, 2 v.

LOPES, G. V. (ed. coord.). Cantigas Medievais Galego-Portuguesas. Corpus Integral Profano. Lisboa: Biblioteca Nacional de Portugal / Instituto de Estudos Medievais / Centro de Estudos de Sociologia e Estética Musical, 2016, 2 v.

MONTALVO, G.R. Amadis de Gaula. Juan Manuel Cacho Blecua (ed.). Madrid: Catedra, 1987, 2 v.

PLÍNIO, El Viejo. Historia Natural. Libros VII-XI. Trad. y notas de E. del Barrio Sanz; I. García Arribas; A. M ${ }^{a}$ Moure Casas; L. A. Hernández Miguel; M ${ }^{a}$ L. Arribas Hernáez. Madrid: Gredos, 2003. (vol. 308 da Biblioteca Clásica Gredos).

QUINTILIANO. Instituição Oratória. Trad., apres. e notas de Bruno Bassetto. Ed. bilíngue. Campinas, SP: Editora da Unicamp, 2015, 2 t.

FOURNIVAL, R. de. Le Bestiaire d'Amour. Suivi de la Reponse de la Dame, enrichi de 48 dessins graves sur bois, publies pour la premiere fois d'apres le manuscrit de la Bibliotheque Imperiale par C. HIPPEAU, a Paris, chez Auguste Aubry, 1860. Consultar: Gallica.bnf.fr/ark:/12148/bpt6k1304386

PHYSIOLOGUS. Michael J. Curley (trad.). Texas: University Press, 1979.

RIQUER, M. de. Los trovadores. História literária y textos. Barcelona: Ariel, 2001, $3 \mathrm{v}$.

SANTO AGOSTINHO. A Cidade de Deus. Contra os pagãos. São Paulo: Vozes, v. II, 1990.

SANTO AGOSTINHO. A Doutrina Cristã. São Paulo: Paulus, 2002.

THEOBALDI Physiologus. P. T. Eden (ed.). Leiden und Köln: E. J. Brill, 1972.

\section{Obras de referência}

BOLOGNA, C., Voz. In: Enciclopédia Einaudi, vol. 11. Lisboa: Imprensa Nacional Casa da Moeda, 1987, pp. 58-92.

DICTIONNAIRE du Moyen Âge. GAUVARD, C; LIBERA, A; ZINK, M. (dir.). $2^{\mathrm{e}}$ ed. Paris: Quadrige/PUF, 2002. 
DICIONÁRIO Houaiss da Língua Portuguesa. $1^{\text {a }}$ ed. Rio de Janeiro: Objetiva, 2001.

CHEVAliER, J. e GHEERBRANT, A. Dictionnaire des Symboles. 10 a ed. Paris: Seghers, 1969.

LANCIANI, G. e TAVANI, G. (org. e coord.). Dicionário da Literatura Medieval Galega e Portuguesa. Lisboa: Caminho, 1993

LE GOFF, J.; SCHMITT, J.C. (eds.). Dicionário Temático do Ocidente Medieval. Bauru, Sp: EDUSC; São Paulo, SP: Imprensa Oficial do Estado, 2002, 2 v.

PLANCY, J. C. de. Dicionário Infernal. São Paulo: EDUSP; Brasília: EDUNB; Rio de Janeiro: Arquivo Nacional, 2019.

WILD Cats of the World. Photographs and drawings by Art Wolfe; text by Barbara Sleeper. N.Y.: Crown Publishers, 1995.

\section{Estudos}

BATISTA NETO, J. História da Baixa Idade Média, 1066-1453. São Paulo: Ática, 1989.

BELTRAN, V. Poética, poesia y sociedad en la lírica medieval. Santiago de Compostela: Universidade, Servizo de Publicacións e Intercambio Científico, 2007 (Verba: Anuario galego de Filoloxia. Anexo 59).

BERGOT, L-P. Introduction à la tradition des bestiaires français (XIIe-XIIIe siècles). Medieval Literatura, Medieval Bestiaires, 2015. https://www.academia.edu/22211282/; acesso em 20/01/2020.

BOLTON, B. A Reforma na Idade Média. Lisboa: Edições 70, 1983.

BREA, M. Les animaux dans les poésies amoureuses des troubadours occitans. Revues des Langues Romanes. 1994:403-431 - Consultar: Academia.edu/39748225.

BROWN, F.J.A.C. Técnicas de persuasão. Da propaganda à lavagem cerebral. $3^{\text {a }}$ ed. Rio de Janeiro: Zahar, 1976.

BUQUET, T. Le guépard médiéval, ou comment reconnaître un animal sans nom. Reinardus. "Le guépard medieval", 23, 2011 p. 12-47.

Consultar: Academia.edu/1177913

CURTIUS, E. R. Literatura Europeia e Idade Média Latina. Rio de Janeiro: MEC Instituto Nacional do Livro, 1957.

DUBY, G. Idade Média, Idade dos Homens. Do Amor e Outros Ensaios. São Paulo: Companhia das Letras, 1989.

DUBY, G. O modelo cortês. In: História das Mulheres. A Idade Média. DUBY, G. e PERROT, M. (dir.). Porto: Afrontamento, 1990, vol. 2, pp. 331-351.

ECO, U. (org.). História da Beleza. Rio de Janeiro: Record, 2007.

EIZIRIK, E. et al. The late Miocene radiation of modern felidae: a genetic assessment. Science. , 2006: vol. 311, pp. 73-77. 
FRANCO JÚNIOR, H. A Eva Barbada. Ensaios de Mitologia Medieval. São Paulo: Edusp, 1996.

HUBERT, E. E. e BENTO, E. J. (orgs.). Retórica e Discurso. Fronteiras e Interfaces: das origens aos desdobramentos atuais. Homenagem à professora Lineide do Lago Salvador Mosca. Campinas, SP: Pontes Editora, 2019.

HUIZINGA, J. O Declínio da Idade Média. São Paulo: Edusp, 1978.

KÖHLER, E. L'aventure chevaleresque: ideal et réalité dans le roman courtois. Paris: Gallimard, 1974.

LA CROIX, A. de. L'érotisme au Moyen Âge. Le corps, le désir, l'amour. Paris: Tallandier, 2003.

LAZARIS, S. Quelques considérations sur l'illustration du Physiologus grec. Bestiaires Médievaux. Brepols Publishers, 2005, pp. 141-167. Disponível em: https://www.academia.edu/795328/_Quelques_considerations_sur_1_illustration_d u_Physiologus_grec_; acesso em 10/06/2020.

LESKY, A. História da Literatura Grega. Lisboa: Fundação Calouste Gulbenkian, 1995.

MENÉNDEZ PIDAL, R. Poesia Juglaresca y Juglares. Orígenes de las literaturas românicas. Madrid: Espasa Calpe, 1969.

MOHENO, L. von der W. (ed.). Retórica Aplicada a la Literatura Medieval y de los siglos XVI y XVII. México: Grupo Destiempos, 2016.

MONGELLI, L. M. A Arte Retórica e a Ciência da Paixão. Veritas, 43(3), 1998, pp. 541-548.

MONGELLI, L.M. (org.) Trivium \& Quadrivium. As Artes Liberais na Idade Média. Cotia: Íbis, 1999.

MONGELLI, L.M. A Indisciplinada Retórica de Platão. In: A Cidade de Deus e a Cidade dos Homens. De Agostinho a Vico. Festchrift para Luis Alberto De Boni. Porto Alegre: Edipucrs, 2004, pp. 335-347.

MOSCA, L.S. (org.). Retóricas de Ontem e de Hoje. São Paulo: Humanitas, 1997.

PAGE, C. The Owl and the Nightingale. Musical Life and Ideas in France 11001300. Berkeley: Universidade da Califórnia, 1989.

PASTOUREAU, M. Une Histoire Symbolique du Moyen Âge Occidental. Paris: Seuil, 2004.

PEREIRO, C. P. M. Natura das Animalhas. Bestiário medieval da lírica profana galego-portuguesa. Vigo: Edicións A nosa Terra, 1996.

PRIEGO, C. C. Las fiestas juglarescas en la España Medieval. In: Fiestas, juegos y espectáculos en la España Medieval. Actas del VII Curso de Cultura Medieval. Madri: Polifemo, 1999, pp. 94-109.

PASCUAL, L. M. La Tradición de los Bestiarios Franceses y su Influencia en la Peninsula Iberica. Estudios Humanísticos. Filología, 36 (2014), 115-140.

PAPAVERO, N. (Museu de Zoologia da USP). Considerações sobre os felinos do Velho Mundo tratados como 'onças': notas históricas e etimológicas. [Coord. da 
série monográfica: Mário Eduardo Viaro]. São Paulo: NEHiLP/FFLCH/USP, 2017. http://www.livrosabertos.sibi.usp.br/portaldelivrosUSP/catalog/view/188/171/8081. Acesso em 20/01/2020.

RICOEUR, P. From Metaphysics to Rhetoric. Netherlands: Kluwer Academic Publishers, 1989.

SCHMITT, J.C. Le corps, les rites, les rêves, le temps. Essais d'anthropologie medievale. Paris: Gallimard, 2001.

SPINA, S. Do Formalismo Estético Trovadoresco. São Paulo: Boletim da Faculdade de Filosofia, Ciências e Letras/USP, 1961.

SPINA, S. Na Madrugada das Formas Poéticas. São Paulo: Ática, 1982.

VARANDAS, A. A Idade Média e o Bestiário. Medievalista on line. Ano 2, n 2, 2006, pp. 1-53.

VASCONCELOS, C. M. O lais galego-português 'Leonoreta, fin roseta!' e as origens do adjectivo 'fin'. In: Dispersos. Originais portugueses. I - Vária. Lisboa: Edição da Revista Ocidente”, 1969, vol. 1, p. 184-185.

VERDON, J. Le plaisir au Moyen Âge. Paris: Perrin, 1996.

VERDON, J. L’amour au Moyen Age. La chair, le sexe et le sentiment. Paris: Perrin, 2006

WOENSEL, M. van. Simbolismo Animal Medieval. Os Bestiários. João Pessoa: Editora Universitária, 2001.

ZUMTHOR, P. Essai de Poétique Médiévale. Paris: Seuil, 1972.

ZUMTHOR, P. A Letra e a Voz. São Paulo: Companhia das Letras, 1987.

\footnotetext{
${ }^{1}$ Convém lembrar que o termo "cortês" foi usado "pela primeira vez por Gaston Paris, em 1883, em um artigo sobre $O$ cavaleiro da charrete, de Chrétien de Troyes", romance que relata o amor perfeito de Lancelote por Guinevere, esposa do rei Artur. (Le Goff.; Schmitt. (eds.), 2002, v. I, verbete "Amor cortesão").

${ }^{2} \mathrm{O}$ tema da "voz" tem significados muito mais amplos e complexos do que é possível aqui desenvolver, inclusive porque transcendem os objetivos deste artigo. Aos interessados, sugere-se a leitura de Bologna 1987, verbete "Voz". Ali, diz o autor: "A sua natureza [da voz] é essencialmente física, corpórea; está relacionada com a vida e com a morte, com a respiração e com o sono; emana dos mesmos órgãos que presidem à alimentação e à sobrevivência. Antes mesmo de ser o suporte e o canal de transmissão das palavras através da linguagem, a voz é um imperioso grito de presença, uma pulsação universal e uma modulação cósmica através de cujos trâmites a história irrompe no mundo da natureza." (grifos meus).

${ }^{3}$ A propósito deste vasto assunto, remeto o leitor para os trabalhos irretocáveis de Hilário Franco Júnior, em especial o artigo "Meu, Teu, Nosso: Reflexões sobre o Conceito de Cultura Intermediária”. (1996, pp. 31-44).

${ }^{4}$ Convém alertar que o assunto - largamente estudado na cronologia de suas nuanças desde a Alta Idade Média e com ampla bibliografia - só interessa aqui marginalmente, na medida em que colabora para esclarecer uma terminologia específica, de uso frequente na ficção lírica e romanesca dos séculos XII e XIII - exatamente o momento que os historiadores consideram de aperfeiçoamento do sistema feudal.

(Para uma consulta rápida, mas consistente, veja o verbete de Robert Fossier, "Féodalité", in: Gauvard et al. 2002).

${ }^{5}$ Brenda Bolton oferece um interessante panorama dessas novidades, que incluem a sistematização de Ordens religiosas como Cluny (910) e Cister (1098), com sua proposta de "imitação de Cristo"; o
} 
aparecimento das Ordens Mendicantes e a disseminação da vida apostólica; a regulação dos casamentos e do celibato clerical; o controle das investiduras (simonia), a instituição da confissão auricular etc. sempre no intuito de estabelecer regras para o melhor cumprimento dos princípios cristãos. (Bolton 1983).

${ }^{6}$ Consultar a base de dados Cantigas medievais galego-portuguesas, online, do Projeto LITTERA, sob coordenação da professora portuguesa Graça Videira Lopes: https://cantigas.fcsh.unl.pt . Ou, em sua versão impressa, 2016, 2v. (Todas as referências ao poema atribuído a Lobeira tomarão por base estas edições).

${ }^{7}$ Cf. nota de rodapé ao texto recolhido em Lírica Profana Galego-Portuguesa, 1996, vol. 2, p. 1000.

${ }^{8}$ Os dois textos da Leonoreta (do segundo falaremos logo adiante) estão bem estudados por Vicenç Beltrán em artigos indispensáveis, reunidos em: Poética, poesia y sociedad en la lírica medieval (v. Bibliografia final): - La cantiga de Alfonso XI y la ruptura poética del siglo XIV (p. 105); Leonoreta / fin roseta y la corte poética de Alfonso XI (p. 119); La Leonoreta del Amadis (p. 133). Este último, também em: Actas del I Congreso de la Asociación Hispánica de Literatura Medieval, ed. de Vicente Beltrán, PPU, 1988, p. 187. Ainda: na Biblioteca Virtual Miguel de Cervantes (Alicante, 2016), Tipos y temas trovadorescos. Leonoreta / fin roseta, la corte poética de Alfonso XI y el origen del Amadís.

${ }^{9}$ O tema da "autoria discutível" do Amadis de Gaula, que aqui mencionamos apenas para situar nosso assunto, está estudado de modo completo pelo editor do exemplar de que nos servimos, Juan Manuel Cacho Blecua, na sua Introdução à obra (v. o capítulo "Datación y autoria"). Montalvo, 1987. ( Todas as referências a esta obra e ao poema nela inserido tomarão por base esta edição). Pontue-se que a querela autoral foi há muito resolvida, a favor da "tese espanhola".

${ }^{10}$ Registre-se: nesta Leonoreta, Vicente Beltrán adota a isometria (como sugeriu Tavani para o poema de Lobeira) e propõe a construção das duas primeiras estrofes como oitavas de versos octossílabos. Exclui a última estrofe e justifica a exclusão: “'”... nem por sua forma, nem por seu conteúdo, nem por seu estilo pode comparar-se com o texto. Sem lugar a dúvidas, forma uma adição posterior" (p. 191, cf. nota 10). Carolina Michaëlis, que também prefere a heterometria na organização das estrofes, já pensava assim quanto à última estrofe, "evidentemente um acrescento posterior", "técnicamente diversa", considerada uma estrofe "explicativa, porque dá solução, assaz enigmática, à adivinha contida nos versos de Lobeira." (Vasconcelos 1969:179). Assim sendo, as referências que nos importam encontram-se nas duas primeiras estrofes.

${ }^{11}$ Assunto dos mais vastos, complexos e fascinantes, foge completamente à alçada do não especialista. Portanto, encaminho os interessados para os numerosos trabalhos do Dr. Eduardo Eizirik, biólogo da PUC do Rio Grande do Sul (a quem agradeço as preciosas orientações), mundialmente conhecido por suas pesquisas nesse campo. Como introdução a elas, consultar Eizirik. et al. 2006, pp. 73-77.

${ }^{12}$ Assim como fará mais tarde Brunetto Latini (c. 1220-1294), cuja obra melhor conhecida, Li Livres dou Tresor, é considerada por vários estudiosos como uma das introdutoras dos bestiários na Península Ibérica. (Pascual 2014).

${ }^{13}$ Michel Pastoureau faz aqui um esclarecedor reparo: nas tradições orientais, principalmente a das fábulas, o leão é quase sempre apresentado com rex omnium bestiarum (= rei de todas as bestas selvagens), mas não ainda como rex animalium (= rei de todos os animais). É preciso esperar as grandes enciclopédias do século XIII para que isto aconteça: autores como Thomas de Cantimpré, Barthélemy l'Anglais e Vincent de Beauvais tratam o leão por "rei dos animais" e dedicam-lhe longas passagens, nas quais sublinham "sua força, sua coragem, sua largesse e magnanimidade". (2004, 57).

${ }^{14}$ Mais tarde, no famoso Dicionário Infernal de J. Collin de Plancy (1793-1881), ainda se mantém a ambiguidade descritiva referente ao leão: "Aquele que usar uma correia feita com sua pele não temerá jamais os inimigos; comendo de sua carne, ou bebendo sua urina durante três dias, cura-se a febre quartã; se tiverdes os olhos desse animal sob a axila, todos os animais fugirão de vós, baixando a cabeça. (...). $\mathrm{O}$ diabo mostrou-se algumas vezes sob a forma de um leão, dizem os demonógrafos". (2019, verbete "leão).

${ }^{15}$ Recorde-se o que diz o Dicionário de Símbolos, em sentido geral, sobre a cor "branca": "da mesma forma que sua contra-cor, o negro, o branco pode situar-se nas duas extremidades da escala cromática. Absoluto, e não possuindo outras variações além daquelas que vão da opacidade ao brilho, significa tanto a ausência como a soma de cores". E mais: o branco é também a cor dos ritos de passagem nascimento/morte; infância/juventude/velhice -, associado que está aos movimentos da luz do Sol, de Leste a Oeste, trazendo cores esmaecidas no nascer e no fim do dia. (1969, verbete "Blanc") 
${ }^{16}$ Observe-se a citação que Eco faz de Hugo de São Vítor: “A respeito da cor das coisas não é preciso discutir longamente, a própria vista demonstra quanta beleza se acrescenta à natureza quando essa é adornada por tantas e diversas cores. O que é mais belo que a luz que, mesmo não tendo cor em si, faz aparecerem as cores de todas as coisas iluminando-as?" (grifo meu) (2007 125).

${ }^{17}$ Dicionarizado em "devanear”, ele significa: “conceber na imaginação; sonhar; fantasiar; pensar em coisas quiméricas; divagar com o pensamento". (Houaiss 2001). 